\title{
Judicial Review of the Exercise of Public Power
}

\author{
Michael Sinclair *
}

\section{INTRODUCTION}

Under Order 53 of the Rules of the Supreme Court, as confirmed by section 31 of the Supreme Court Act 1981, the procedure by which the remedy of judicial review is made available is by way of application for judicial review. The function of this remedy, and of the former prerogative writs, is the control of the manner in which power is exercised - usually in the hands of the executive and executive agencies under statute, and more rarely in the hands of the Crown in the form of the Royal prerogative. The one feature distinguishing power which is subject to this kind of control from other forms of power is its public character. The courts are re-defining, in broader terms, the kind of power that is to be regarded as of a public character. The result is that the exercise of power once thought to be immune from challenge may now fall within the supervisory jurisdiction. At the root of this view is the idea that the aggregation of power, the exercise of which affects the public without recourse, is in some way contrary to public policy and should be subject to restraint. Of course, this idea and its implementation are two different things. Implementation requires the formulation of boundaries beyond which the courts may not venture.

This article examines the ways in which the courts have re-defined some of the requirements to be established in an application for judicial review in assuming a greater supervisory jurisdiction over the exercise of power. For this purpose, attention is focused on the criteria being applied by the courts in establishing jurisdiction to review the exercise of power and on the effect that the existence of a contract may have on establishing that jurisdiction.

\section{JURISDICTION}

Under the old prerogative writ system, whether a matter was sufficiently public so as to attract the supervisory jurisdiction was tested by reference to the source of the power being exercised. Section 29 of the Supreme Court Act 1981 provides that the High Court shall have jurisdiction to make orders of mandamus, prohibition and certiorari in those classes of cases in which it had power to do so immediately

*W. M. Tapp Scholar, Gonville and Caius College, Cambridge. 
before the passing of the Act. Thus the new procedure of an application for judicial review, laid down by Order 53 and section 31 of the Supreme Court Act 1981, did not alter the jurisdictional requirements of the prerogative writs, but merely provided that relief in respect of them could only be obtained by way of an application for judicial review under Order 53.

Under the new procedure the source of the power remained, at least initially, the decisive test. The existence of statutory power was treated as the touchstone, ${ }^{1}$ although later the existence of power deriving from the Royal prerogative was added as a source. ${ }^{2}$ Likewise, the exercise of power by non-statutory bodies like the Criminal Injuries Compensation Board - which was set up by the Royal prerogative - has been held to be subject to the supervisory jurisdiction. ${ }^{3}$

The expansion of jurisdiction by determining it according to a consideration of the nature of the power was heralded by what has become a landmark decision of the English Court of Appeal. The case of $R$. v. Panel of Take-overs and Mergers, ex parte Datafin p.l.c. ${ }^{4}$ concerning a decision of the Panel on Take-overs and Mergers (the "Panel"), is well-known. ${ }^{5}$ The Panel is an unincorporated association. It has no statutory, prerogative or common law powers. It promulgates and polices the City Code on Take-overs and Mergers - the body of rules that members of the Stock Exchange are expected to obey in making take-over bids. In effect, it wields a decision-making power of life or death, as offenders against the Code - as determined by the Panel - can be banned from the Stock Exchange. The Panel is a self-regulating body in the sense that it connotes a system whereby a group of people, acting in concert, use their collective power to force themselves and others to comply with a code of conduct of their own devising. ${ }^{6}$ The Master of the Rolls, Sir John Donaldson, described the Panel as performing its functions without visible or direct means of legal support, although

1. H. W. R. Wade, Administrative Law 6th ed. (1988), p. 629.

2. Council of Civil Service Unions v. Minister for the Civil Service [1985] A.C. 374.

3. R. v. Criminal Injuries Compensation Board, ex parte Lain [1967] 2 Q.B. 864.

4. [1987] 1 All E.R. 564.

5. A. I. M. Tompkins, "Judicial Review and the Public Domain", [1987] N.Z.L.R. 120; Lord Alexander of Weedon, "Judicial Review and City Regulators", [1989] 52 M.L.R. 640; C. F. Forsyth, "The Scope of Judicial Review: 'Public Duty' Not 'Source of Power" ", [1987] P.L. 356; H. W. R. Wade, "New Vistas of Judicial Review", (1987) 103 L.Q.R. 323; L. Hilliard, "The Take-over Panel and the Courts", [1987] 50 M.L.R. 372; G. A. Smith, "Public Duty and Private Power in Administrative Law", (1990) 40 University of Toronto Law Fournal 412; A. C. Hutchinson, "Mice Under a Chair; Democracy, Courts and the Administrative State", (1990) 40 University of Toronto Law Fournal 374; D. Oliver, "Is the Ultra Vires Rule the Basis of Judicial Review?", [1987] P.L. 543; D. Pannick, "Who is Subject to Judicial Review and in Respect of What?", [1992] P.L. 1; H. W. R. Wade, "Beyond the Law: A British Innovation in Judicial Review", 43 Admin. L. Rev. 559; P. Cane, "Self Regulation and Judicial Review", (1987) 6 Civilyustice Quarterly 324; J. Beatson, "The Courts and the Regulators", (1987) 3 Professional Negligence 121; S. K. M. Wong, "Judicial Review; Power and Public Functions", (1987) 131 S.f. 1674; H. Woolf, "Judicial Review: A Possible Programme for Reform", [1992] P.L. 221; C. Lewis, fudicial Remedies in Public Law (1992), p. 31 et seq..

6. [1987] 1 All E.R. 564, 567 per Sir John Donaldson MR. 
he noted that there is abundant invisible or indirect support. ${ }^{7}$ In particular, the background matrix of governmental involvement and statutory backing was noted to include: (1) the unspoken assumption that the Department of Trade and Industry, the Stock Exchange or other appropriate body would in fact exercise statutory or other contractual powers to penalise transgressors of the Code; (2) statutory powers able to be exercised by the Bank of England in the event of a breach of the Code; (3) the fact that the Governor of the Bank of England appoints both the Panel's chairman and deputy chairman; and (4) its origins of establishment by the Bank of England. With a consideration of these and other criteria discussed below, the Master of the Rolls and Lloyd LJ spoke of a test of jurisdiction which was, it seems, to be regarded as one of general application. Rejecting the Panel's argument that jurisdiction for judicial review extends only to bodies whose power is derived from legislation or the Royal prerogative, the Master of the Rolls said, in what has become a frequently cited passage, that: ${ }^{8}$

"Possibly the only essential elements are what can be described as a public element, which can take many different forms, and the exclusion from the jurisdiction of bodies whose sole source of power is a consensual submission to its jurisdiction."

Addressing the question in terms of the source and nature of the power, Lloyd LJ said: ${ }^{9}$

"I do not agree that the source of the power is the sole test whether a body is subject to judicial review. . . . Of course the source of the power will often, perhaps usually, be decisive. If the source of power is a statute, or subordinate legislation under statute, then clearly the body in question will be subject to judicial review. If, at the other end of the scale, the source of power is contractual, as in the case of private arbitration, then clearly the arbitrator is not subject to judicial review ...

But in between these two extremes there is an area in which it is helpful to look not just at the source of the power but at the nature of the power. If the body in question is exercising public law functions, or if the exercise of its functions have public law consequences, then that may, as counsel for the applicants submitted, be sufficient to bring the body within the reach of judicial review."

The courts have been prepared to apply both the source and nature of the power 
tests. If jurisdiction is established by one or the other, then that will be sufficient. ${ }^{10}$ But in a growing number of cases the nature of the power test has been applied as if it alone were the test of general application, ${ }^{11}$ and this is to be welcomed. It marks the taking of a more flexible approach to the whole question of jurisdiction and, in particular, the application of a functional analysis of the wider constitutional role of bodies whose decisions are sought to be challenged in this way.

A recent Court of Appeal decision attempts to narrow the scope of application of the nature of the power test in Datafin. In $R$. v. Disciplinary Committee of the fockey Club, ex parte His Highness The Aga Khan ${ }^{12}$ the Court of Appeal was called upon to decide whether a decision of the Disciplinary Committee of the Jockey Club disqualifying the applicant's horse under the Rules of Racing could be challenged by way of judicial review. It was accepted that a contract existed between the applicant and the Jockey Club under which the former agreed to be bound by the latter's Rules of Racing. The Court of Appeal held that the decision could not be challenged by way of judicial review. The reasons given for the decision are examined below, but for present purposes it is sufficient to note that the Court of Appeal was of the view that jurisdiction under the principle in Datafin would only be appropriate where what is being exercised is "governmental" power. Quite why "governmental" power should differ from power which is sufficiently public is difficult to see. The Court did not attempt to describe the attributes of governmental power, except to say that the Panel was exercising governmental power because it was woven into the fabric of public regulation, ${ }^{13}$ whereas the Jockey Club was not. What is required, according to Hoffmann $L J$, is that the body in question be a "surrogate organ of government", 14 and that this might be

10. In R. v. Royal Life Saving Society, ex parte Howe (unreported, Court of Appeal, 15 May 1990, Lloyd and McCowan LJJ, and Sir John Megaw, LEXIS) Lloyd LJ stated that, since Datafin, there have been two separate tests for jurisidiction - the nature of the power and the source of the power. Both were applied in that case in deciding the question of jurisdiction; Stuart-Smith $\mathrm{LJ}$ in $R$. v. fockey Club, ex parte R.A.M. Race-courses Ltd. (1991) 3 Admin.L.R. 265, 290 said: " . . each case will depend on the source of powers and nature of functions of the body and whether there is a sufficient public element involved."

11. In R. v. Jockey Club, ex parte Massingberd-Mundy (1990) 2 Admin.L.R. 609 (Q.B.D.) Neill LJ was of the view that it is the public element in the relevant body's decision rather than the source from which its powers are derived which is likely to provide the surest answer to the question whether the decisions of that body can be reviewed by the process of judicial review. In $R$. v. Civil Service Appeal Board, ex parte Bruce [1988] 3 All E.R. 686(Q.B.D.) May LJ stated at p. 961 that the test of a sufficient public element, which focuses on the nature of the power, as laid down in Datafin, was a general test for application in all cases of judicial review, whether concerning powers whose source is statutory, prerogative or otherwise. Similarly, Auld J in R. v. The Imam of Bury Park fame Masjid Luton, Abdul Bari and Others, ex parte Sulaiman Ali (unreported, Queen's Bench Division, 30 August 1991, LEXIS) said that the essential qualification for judicial review of the exercise of a power was its public element. This statement, it seems, was to be regarded as one of general application.

12. Unreported, Court of Appeal, transcript of the draft judgments of 4 December 1992 (unrevised), Sir Thomas Bingham MR, Farquharson and Hoffmann LJJ, (references to page numbers refer to the page number of the appropriate separately numbered judgment being referred to).

13. Per Sir Thomas Bingham MR, at p. 17.

14. At p. 4. 
indicated by a delegation of power from government of some sort - in other words, a "privatisation of the business of government itself". 15

The distinction that the Court of Appeal attempted to draw between public and governmental power is problematic and should be resisted. Although it is true that the Panel could be said to be exercising governmental power, the Court of Appeal in Datafin did not seek to make a distinction between public and governmental power, and indeed Sir John Donaldson MR in that case said that all that might be required was a public element. The decision in Datafin has given the courts a flexible tool by which to make an analysis, at a functional level, of the true nature of the exercise of power and it would be regrettable indeed if that were to be narrowed in its scope of application in the way suggested by the Court of Appeal in The Aga Khan.

What is meant by the "nature of the power"? Woolf L J considered its meaning in $R$. v. Derbyshire County Council, ex parte Noble. ${ }^{16}$ He stated ${ }^{17}$ that the approach which the courts now adopt is to look at the subject-matter of the decision which it is suggested should be subject to judicial review, and the actual, factual application of the decision-making power. In effect, the "nature" of a power means the "public nature" of a power. The public nature of a power is tested by whether there is a "sufficient public element". As to the meaning of a "sufficient public element", Dillon LJ in McLaren v. The Home Office ${ }^{18}$ equated it with "rights under public law". In $R$. v. Derbyshire County Council, ex parte Noble ${ }^{19}$ Dillon LJ said that the "public element may take the form of a public right on one side, or a public duty on the other side, but there must be a public element." Whether there is a sufficient public element is assessed by reference to a number of criteria which the courts apply in carrying out what is essentially a qualitative assessment of the "publicness" of the power being exercised. Time and again the courts have emphasised that these criteria are not, of themselves, conclusive of jurisdiction. ${ }^{20}$ Ultimately, whether the courts are prepared to extend jurisdiction under the nature of the power test is a question of public policy. This was explicitly recognised in Datafin itself, where Lloyd LJ said that he was not persuaded that

15. Per Hoffmann LJ, at p. 3 .

16. [1990] I.R.L.R. 332 (C.A.).

17. At p. 336.

18. [1990] I.R.L.R. 338, 339.

19. [1990] I.R.L.R. 332, 337.

20. R. v. Code of Practice Committee of the British Pharmaceutical Industry, ex parte Professional Counselling Aids Ltd. (1991) 3 Admin. L.R. 697, 718 per Popplewell J: "There is no one test which is decisive."; R. v. Fockey Club, ex parte Massingberd-Mundy (1990) 2 Admin L.R. 609, per Neill LJ at pp. 624-625: "It is plain that in order to determine whether the decisions of a particular body can be reviewed by the process of judicial review it is not always sufficient to apply a single test.", and per Roch J at p. 628: "I would suggest that these tests are no more than tools used by the courts to reach a resolution of the fundamental question, and further that no one test is necessarily decisive."; $R$. $v$. Derbyshire County Council, ex parte Noble [1990] I.R.L.R. 332, 334 per Woolf LJ: "Unfortunately in my view there is no universal test which will be applicable to all circumstances which will indicate clearly and beyond peradventure as to when judicial review is or is not available." 
there were compelling policy arguments against review of the Panel's decisions. ${ }^{21}$

What follows is an examination of the types of criteria that the courts are likely to take into account, together with observations as to their relative significance.

\section{Nature of the body}

There are several statements by the courts to the effect that both the body and its decision must be of a sufficient public character in order for the decision to be able to be challenged. ${ }^{22}$ However, other cases reject this view and suggest tht it is only the decision (or the exercise of power) that need have a sufficient public element. ${ }^{23}$ In The Aga Khan the Court of Appeal unfortunately concentrated to a large extent on the legal status and characteristics of the Jockey Club, rather than taking a qualitative analysis of the nature of the power it exercises, in deciding that jurisdiction was not established to challenge the decision to disqualify. Sir Thomas Bingham MR was of the view that jurisdiction was not established because the Jockey Club was not in its origin, history, constitution or membership a public body. With respect, this approach represents an unfortunate re-assertion of a more formalistic way of assessing the public character of the exercise of power. Why should the legal characteristics of the body itself dictate the nature of the power it exercises? As Hoffmann LJ in The Aga Khan himself acknowledged, ${ }^{24}$ there "is no reason why a private club should not also exercise public powers." While it cannot be disputed that no decision stands in a vacuum separately from the body that makes it, ${ }^{25}$ the better view is that the test created by Datafin and the cases that follow it is a nature of the power test. It is not a nature of the body and power test. For that reason a more qualitative approach to the nature of the power exercised by the Jockey Club would have been preferable.

However, it is appropriate to have regard to the nature of the body in assessing the sufficiency of the public element where the status of the body 'flavours' the decision. Criteria of this type include such matters as whether the body is selfregulatory and whether it has de jure authority. Whether a body is self-regulatory ${ }^{26}$

21. [1987] 1 All E.R. 564, 582.

22. R. v. Fockey Club, ex parte Massingberd-Mundy (1990) 2 Admin L.R. 609, at p. 627 per Neill LJ; $R$. v. The Football Association Ltd., ex parte The Football League Ltd. (unreported, Queen's Bench Division, 31 July 1991, Rose J, LEXIS); $R$. v. Fernhill Manor School, ex parte Brown (unreported, Queen's Bench Division, 22 May 1992, Brooke J, LEXIS). In The Aga Khan one of the reasons the Court of Appeal gave for holding that jurisdiction to review a decision of the Jockey Club was not established was that it was not in its origin, history, constitution or, least of all, its membership a public body.

23. R. v. Jockey Club, ex parte R.A.M. Race-courses Ltd. (1991) 3 Admin.L.R. 265, at pp. 294-295 per Simon Brown J.

24. At p. 1 .

25. R. v. The Football Association Ltd., ex parte The Football League Lid. (unreported, Queen's Bench Division, 31 July 1991, Rose J, LEXIS).

26. See P. Cane, "Self Regulation and Judicial Review", (1987) 6 Civil fustice Quarterly 324; A. Page, "Self Regulation: The Constitutional Dimension", [1986] 49 M.L.R. 141; J. Beatson, "The Courts and the Regulators", (1987) 3 Professional Negligence 121; P. Bovey, "Company Law Lecture - Self Regulation", (1991) 12 Co. Law. 3. 
is a criterion which has, on occasion, pointed to there being a sufficient public element. Self-regulation in this context was defined in Datafin to mean "a system whereby a group of people, acting in concert, use their collective power to force themselves and others to comply with a code of conduct of their own devising."27 Lloyd LJ took the view that the Panel is a self-regulating body. He said that "the word 'self-regulation' may be misleading. The $[\mathrm{P}]$ anel regulates not only itself, but all others who have no alternative but to come into the market in a case to which the code applies." 28 The self-regulating character of many of the bodies which have been subject to jurisdiction conferred by the standard of a sufficient public element has been referred to in other cases also. ${ }^{29}$ Self-regulation in the sense discussed is relevant only to the extent that it indicates that the rights of others are affected by the exercise of power by a self-regulating body regardless of choice or consent.

In Datafin, the Master of the Rolls observed that the Panel lacked any authority de jure. ${ }^{30}$ In $R$. v. Committee of Advertising Practice, ex parte The Bradford Exchange Ltd. ${ }^{31}$ jurisdiction to review a decision of the Committee of Advertising Practice was assumed for the reason that the Committee is "a self-appointed body, with power which it arrogates to itself . ..". In assuming jurisdiction to review a decision of the Advertising Standards Authority, Glidewell LJ in $R$. v. Advertising Standards Authority, ex parte The Insurance Service p.l.c. ${ }^{32}$ noted that the Authority has no powers granted to it by statute or at common law. Other clear cases involving bodies which have no de jure authority but which were held subject to the supervisory jurisdiction include $R$. v. General Council for the Bar, ex parte Percival, ${ }^{33} R$. v. Ethical Committee of St. Mary's Hospital (Manchester), ex parte Harriott ${ }^{34}$ and $R$. v. Code of Practice Committee of the British Pharmaceutical Industry, ex parte Personal Counselling Aids. ${ }^{35}$

\section{Effect of code}

What is meant by a 'code' in this context? A code means any system of rules which governs a body's exercise of power. These rules can be wholly self-imposed and able to be amended from time to time by the body itself, or they may be imposed by a higher body or even by statute or regulation, and able to be amended subject to requirements contained therein. A code may take the form of an unincorporated association's regulatory guide as to the matters that will be taken into account and

27. [1987] 1 All E.R. 564, 567 per Sir John Donaldson MR.

28. [1987] 1 All E.R. 564, 582.

29. E.g., R. v. Chief Rabbi, ex parte Wachmann (1991) 3 Admin.L.R. 721, 727-728.

30. [1987] 1 All E.R. 564, 567.

31. Unreported, Queen's Bench Division, 31 July 1990, Kennedy J, LEXIS.

32. (1990) 2 Admin.L.R. 77 (Q.B.D.).

33. (1990) 2 Admin.L.R. 711. See the discussion of this case by H.W. R. Wade, "Beyond the Law: A British Innovation in Judicial Review", 43 Admin.L.Rev. 559, 560-561.

34. [1988] 1 F.L.R. 512.

35. (1991) 3 Admin.L.R. 697. 
the procedure to be followed in making a decision, ${ }^{36}$ the memorandum and articles of association (and any rules made under or incorporated into the same) of a company incorporated under the Companies Act 1985 (and its antecedents), ${ }^{37} \mathrm{a}$ statement of objects of a trade association (whether incorporated or not) ${ }_{2}^{38}$ a Royal charter ${ }^{39}$ and the like.

The general rule is that, in assessing whether the exercise of power has about it a sufficient public element, the courts will examine the content and function of any code which regulates the exercise of that power. ${ }^{40}$ Although beyond the scope of this article, it is sufficient for present purposes to note that the content of a code is also relevant to the grounds upon which a decision or exercise of power may be challenged.

When will the courts have regard to the content and function of a code in assessing the public element? The courts will have regard to the content of a code when, say, it shows that a decision made under it was essentially one of religious significance about which public law is not concerned. ${ }^{41}$ Sometimes, the courts will

36.R. v. Panel on Take-overs and Mergers, ex parte Datafin p.l.c. [1987] 1 All E.R. 564; R. v. Panel on Take-overs and Mergers, ex parte Guinness p.l.c. [1989] 1 All E.R. 509.

37. Bank of Scotland v. Investment Management Regulatory Organisation Lid. 1989 S.L.T. 432, 436; R. v. Advertising Standards Authority Ltd,, ex parte The Insurance Service p.l.c. (1990) 2 Admin.L.R. 77.

38. Shearson Lehman Hutton Inc. v. Maclaine Watson E Co. Ltd., f. H. Rayner (Mincing Lane) Ltd. [1989] 2 Lloyd's Law Reports 570 . Although the matter at issue in Shearson was essentially a dispute in private law as to contract, the case has public law implications: R. Goode, "The Concept and Implications of a Market in Commercial Law", (1990) 24 Is.L.R. 185.

39. The courts will give some weight to the contents of a Royal charter as helping the courts to evaluate the extent to which there is a public element about the power conferred: $R$. v. Fockey Club, ex parte Massingberd-Mundy (1990) 2 Admin L.R. 609, at pp. 625-626 per Neill LJ. The courts will not accept arguments to the effect that mere incorporation by Royal charter means that the power so conferred is reviewable as being an exercise of the Royal prerogative: $R$. v. Fockey Club, ex parte Massingberd-Mundy (1990) 2 Admin L.R.. 609 per Neill LJ, at pp. 625-626, but a contrary view appears to be expressed by Roch J in the same case at p. $629 ; R$. v. Fockey Club, ex parte R.A.M. Race-courses Ltd. (1991) 3 Admin. L. R. 265, at pp. 294-295 per Simon Brown J; R. v. Royal Life Saving Society, ex parte Howe (unreported, Court of Appeal, 15 May 1990, per Lloyd LJ, LEXIS); R. v. Disciplinary Committee of the Jockey Club, ex parte His Highness the Aga Khan (unreported, Court of Appeal, transcript of the draft judgments of 4 December 1992 (unrevised), Sir Thomas Bingham MR, Farquharson and Hoffmann LJJ).

40. R. v. Football Association of Wales, ex parte Flint Town United Football Club (unreported, Queen's Bench Division, 11 July 1990, Farquharson, LJ and Nolan J, LEXIS); $R$. v. fockey Club, ex parte Massingberd-Mundy (1990) 2 Admin L.R. 609, at pp. 625-626 per Neill LJ: "On the other hand an examination of the Charter and of the powers conferred on the Jockey Club strongly suggest that in some aspects of its work it operates in the public domain and that its functions are at least in part public or quasi-public functions."; $R$. v. Fockey Club, ex parte R.A.M. Race-courses Ltd. (1991) 3 Admin. L.R. 265, at pp. 294-295 per Simon Brown J: “. . . I agree that the incorporation of the Jockey Club under charter with effect from 1970 cannot of itself be a decisive consideration in attracting the review jurisdiction. On the other hand, I do not regard it as an irrelevance. Rather, it seems to me to indicate a governmental (in the widest sense) recognition of the national importance of the Jockey Club's position...".

41. R. v. The Imam of Bury Park Yame Masjid Luton, Abdul Bari and Others, ex parte Sulaiman Ali (unreported, Queen's Bench Division, 30 August 1991, Auld J, LEXIS). Here Auld J had regard to the provisions of a written constitution under which the decision challenged was made in deciding that the 
regard the function of a code as being that of constituting a contract between the applicant and decision-maker. The extent to which the presence of a contract negates jurisdiction is examined below, but for now it is sufficient to note that the courts will sometimes regard a code which constitutes a contract in this way as negativing the requisite public element. 42

Codes which are in some way linked with statute or subject to informal Departmental or Ministerial approval are likely to be accorded particular importance with regard to their content and function. Thus in Bank of Scotland $\mathrm{v}$. Investment Management Regulatory Organisation Ltd., ${ }^{43}$ a Scottish case, Lord Cullen in the Court of Session held that a company which was a self-regulating organisation within the meaning of the Financial Services Act 1986 was subject to the supervisory jurisdiction. In finding a sufficient public element about the exercise of power of waiver under its conduct of business rules (a code), Lord Cullen had particular regard to the fact that the code was required, at a Departmental or Ministerial level, to be in accordance with the requirements of the Act, and that the code would inevitably bear a close relationship to the Act's requirements. He also had regard to the close relationship between the company's memorandum and articles of association and the purpose and terms of the Act. Jurisdiction was conceded on appeal, but it is clear that there was agreement with Lord Cullen's analysis in this regard.

\section{Government involvement}

The courts have regard to the extent of actual or potential government involvement in assessing the sufficiency of the public element. Government involvement in this sense means government recognition in the widest sense, and will include such matters as the origin of establishment of the body, whether it or its functioning is in any way under-pinned by statute, whether there has been an express or implied devolution of power from government and a consideration of whether the government would otherwise step in and carry out the functions of the body in its absence. These are examined in turn.

In Datafin, one of the matters taken into consideration by both Lloyd and Nicholls LJJ in conferring jurisdiction was the way in which the Panel came to be established. In particular, the leading role played by the Bank of England in setting up and running the Panel and the fact that the Governor of the Bank of England appoints both the chairman and deputy were matters taken into account. Similarly, in $R$. v. Fockey Club, ex parte Massingberd-Mundy Roch J said 44 that "the courts will look at the source of the existence of the body concerned."

decision had an insufficient public element for purposes of jurisdiction, containing as it did matters of religious significance which the court did not regard as of a public character.

42. E.g., R. v. Football Association of Wales, ex parte Flint Town United Football Club (unreported, Queen's Bench Division, 11 July 1990, Farquharson LJ and Nolan J, LEXIS).

43. 1989 S.L.T. 432. See A. Mennie, "Jurisdiction and Competency in Proceedings for Judicial Review", 1990 S.L.T. 1.

44. (1990) 2 Admin L.R. 609, 628. 
The courts will regard an express or implied devolution of power from government as a relevant factor in assessing the public element. In Datafin, Lloyd LJ was of the view ${ }^{45}$ that in that case there was an implied devolution of governmental power to the Panel. Sir John Donaldson MR referred to that implied devolution as being that as "an act of government it was decided that, in relation to take-overs, there should be a central self-regulating body . ..${ }^{46} \mathrm{He}$ also referred to "the express willingness of the Secretary of State for Trade and Industry to limit legislation in the field of takeovers and mergers and to use the [P]anel as the centre-piece of his regulation in that market."47 In The Aga Khan Hoffmann LJ referred to those bodies like the Panel, the Advertising Standards Authority and Investment Management Regulatory Organisation Ltd. - all of which have been subject to judicial review on Datafin principles - and said that they are the result of the "privatisation of the business of government itself." $48 \mathrm{He}$ said that the same could not be said of the Jockey Club, and for that reason, among others, its decisions were not reviewable. This approach is to be compared with that taken in the Australian case of Forbes v. New South Wales Trotting Club Ltd. ${ }^{49}$ This was a case not concerning judicial review but it has been subsequently interpreted in Australia as authority relevant to the issue of jurisdiction for judicial review. ${ }^{50}$ One factor which the High Court considered relevant in deciding that the requirements of the rules of natural justice applied was that the Club controlled trotting in New South Wales by the tacit consent of government. ${ }^{51}$

In relation to an express devolution of power from government, an obvious example that comes to mind is the process of privatisation. Where there is an express devolution of power in this way, it could be that the nature of the power remains essentially public notwithstanding a change in the body which exercises it. Much will depend on the extent to which government remains involved in the decision-making of the privatised industries and whether regulatory power has been delegated to them in this way.

In assessing the sufficiency of the public element, the courts have developed a "but for" test relating to potential government intervention or involvement: "but for the fact that the relevant body is regulating the activities of others in a particular field, would the government otherwise intervene and regulate that

45. [1987] 1 All E.R. $564,585$.

46. [1987] 1 All E.R. 564, 574.

47. [1987] 1 All E.R. 564, 577.

48. At p. 3.

49. 143 C.L.R. 242 (High Court of Australia).

50. "Sydney" Training Depot Snapper Island Ltd. v. Brown (1987) 14 A.L.D. 464 (Federal Court of Australia); Della-Vedova and Another v. State Energy Commission of Western Australia (1990) 2 W.A.R. 561, 568 per Ipp J (Supreme Court of Western Australia); S. D. Hotop, Principles of Australian Administrative Law 6th ed. (The Law Book Company Limited, Sydney, 1985), pp. 271-272.

51. 143 C.L.R. 242, at p. 262 per Gibbs J. 
activity?" 52 Thus, of relevance is whether government would otherwise enact legislation to regulate the area in question. ${ }^{53} \mathrm{Also}$ relevant is whether a government department would otherwise intervene to regulate the area or to set up a public body to do so. ${ }^{54}$ Thus in The Aga Khan a majority ${ }^{55}$ of the Court of Appeal were of the view that if the Jockey Club were dissolved there is nothing to suggest that the government would set up a statutory body to regulate racing, and that this was one reason why the decision was not amenable to judicial review. However, it should be borne in mind that actual or potential government involvement or intervention is not an essential requirement for the establishment of a sufficient public element, ${ }^{56}$ although of course it will greatly add weight to the applicant's case. Other criteria in combination may equally confer jurisdiction. Moreover, the efficacy of a "but for" test for potential government involvement is at least doubtful. Why should the jurisdiction of the court depend on a hypothesis as to what government would do but for the existence of the body in question?57

The correlative of the "but for" test would appear to be "was government formerly controlling or regulating the activity?" If so, why should it not be the case that the courts retain a supervisory jurisdiction in respect of that activity upon its delegation when it remains sufficiently public? Such an approach is suggestive of the view that power formerly exercised by government and since delegated by way of privatisation might come within the supervisory jurisdiction.

52.R. v. Chief Rabbi, ex parte Wachmann (1991) 3 Admin. L.R. 721, 727-728 per Simon Brown J: “And certainly it is a feature of all these cases that, were there no self-regulatory body in existence, Parliament would almost inevitably intervene to control the activity in question."; D. Pannick, "Who is Subject to Judicial Review and in Respect of What?", [1992] P.L. 1, 5-6.

53. In R. v. Chief Rabbi, ex parte Wachmann (1991) 3 Admin. L.R. 721, 727-728, in holding that there was an insufficient public element for jurisdiction to review a decision of the Chief Rabbi, Simon Brown J took into account that it cannot be suggested that "but for his offices the government would impose a statutory regime." This was also one of the reasons why jurisdiction in respect of a decision of an Imam was refused in $R$. v. The Imam of Bury Park Fame Masjid Luton, Abdul Bari and Others, ex parte Sulaiman Ali (unreported, Queen's Bench Division, 30 August 1991, Auld J, LEXIS). In $R$. v. Panel on Take-overs and Mergers, ex parte Datafin p.l.c. [1987] 1 All E.R. 564, 574 the Master of the Rolls said that no one could have been in the least surprised if the Panel had been instituted and operated under the direct authority of statute law. In $R$. v. Fockey Club, ex parte R.A.M. Race-courses Ltd. (1991) 3 Admin L.R. 265, at pp. 294-295 Simon Brown J stated that one factor pointing to jurisdiction is whether the powers so exercised "could as well have been eshrined in legislation."

54. In $R$. v. Advertising Standards Authority Ltd., ex parte The Insurance Service p.l.c. (1990) 2 Admin. L.R. 77, 86 one reason for the conferral of jurisdiction over the decisions of the Advertising Standards Authority was that "it is clearly exercising a public law function which, if the Authority did not exist, would no doubt be exercised by the Director General of Fair Trading." In $R$. v. The Football Association Ltd., ex parte The Football League Ltd. (unreported, Queen's Bench Division, 31 July 1991, Rose J, LEXIS), Rose J stated that, in Datafin, one of the reasons for the conferral of jurisdiction in respect of the Panel was that, "but for its existence, the State would create a public body to perform its functions."

55. Farquharson and Hoffmann LJJ.

56. R. Gordon, "Judicial Review", (1992) 136 S.F. 109.

57. D. Pannick, "Who is Subject to Judicial Review and in Respect of What?", [1992] P.L. 1, 5-6. 
In assessing the sufficiency of the public element, the courts have given particular weight to whether the establishment or functioning of the body, or the exercise or enforcement of its powers of decision, are in any sense supported or under-pinned by statute or regulation..$^{58}$ For example, the extent of statutory under-pinning is considered to be a highly relevant factor in deciding whether there is a sufficient public element for purposes of judicial review in cases of employment by the Crown, ${ }^{59}$ and in the case of The Aga Khan one of the reasons given for why jurisdiction was not established was because the Jockey Club had largely escaped mention in the statute books. Moreover, the Court of Appeal stressed the fact that the Jockey Club had not been woven into any system of governmental control of horse racing - it had not been "woven into the fabric of public regulation." Sometimes there will be sufficient public element if a code (under which there is contained a power the exercise of which is subject to challenge) is under-pinned by, or reflects the requirements of, a statute. ${ }^{60}$

The under-pinning must relate to the matter at issue in the application for review if it is to be regarded as of any weight when considering the sufficiency of the public element. ${ }^{61}$ The reason why the statutory under-pinning is required to relate to the matter at issue is because the nature of the power test focuses on the public character of the exercise of power and not on the public character of the body exercising that power. Statutory under-pinning of the body itself may not relate in any real sense to the power it exercises. It is statutory under-pinning of the exercise of power that is relevant. It is possible to envisage a situation where the

58. In $R$. v. Panel on Take-overs and Mergers, ex parte Datafin p.l.c. [1987] 1 All E.R. 564, 574 the Master of the Rolls noted that the Panel was "supported and sustained by a periphery of statutory powers and penalties ...". In R. v. Chief Rabbi, ex parte Wachmann (1991) 3 Admin. L.R. 721, 727-728 Simon Brown J said: "In other words, where non-governmental bodies have hitherto been held reviewable, they have generally been operating as an integral part of a regulatory system which, although itself non-statutory, is nevertheless supported by statutory powers and penalties clearly indicative of government concern." In $R$. v. The Imam of Bury Park fame Masjid Luton, Abdul Bari and Others, ex parte Sulaiman Ali (unreported, Queen's Bench Division, 30 August 1991, Auld, J. LEXIS), one reason for refusing jurisdiction was that there was no statutory under-pinning. A similar result for a similar reason was reached by Rose $\mathrm{J}$ in $R$. v. The Foorball Association Lid., ex parte The Football League Lid. (unreported, Queen's Bench Division, 31 July 1991, Rose J, LEXIS). See also R. v. Fernhill Manor School, ex parte Brown (unreported, Queen's Bench Division, 22 May 1992, Brooke J, LEXIS). 59. E.g., R. v. East Berkshire Health Authority, ex parte Walsh [1984] I.R.L.R. 278, at p. 280 per Sir John Donaldson MR; $R$. v. Secretary of State for the Home Department, ex parte Benwell [1985] 1 Q.B. 554, at p. 573 per Hodgson J.

60. Bank of Scotland v. Investment Management Regulatory Organisation Limited 1989 S. L.T. 432. For a case where a code was not sufficiently under-pinned by statute, so that the requisite public element was not established, see $R$. v. The Independent Broadcasting Authority, exparte the Rank Organisation p.l.c. (unreported, Court of Appeal, 26 March 1986, May and Lloyd LJJ and Sir John Megaw, LEXIS). 61. In R. v. Derbyshire County Council, ex parte Noble [1990] I.R.L.R. 332, at p. 334 Woolf LJ said, in the context of an application for review of a decision by a council to dismiss the applicant from his employment, that statutory under-pinning which relates to the right to dismiss can be significant in indicating that the employment is of the category where judicial review may be available. At p. 335 Woolf $\mathrm{L}$ stated that although there was a statutory under-pinning in the present case, it did not relate to dismissal and so of itself was insufficient to establish jurisdiction. 
exercise of one type of power (say, financial expenditure and borrowing by a body) might be under-pinned by statute, while the exercise of another of the body's powers (say, the power to discipline members) may be wholly free from statutory under-pinning. The under-pinning of the former would be irrelevant in any assessment of the sufficiency of any public element in any challenge to the exercise of the latter.

Statutory under-pinning relevant to the matter at issue is not an essential or necessary criterion for the establishment of jurisdiction. ${ }^{62}$ Other criteria in combination can be sufficient to establish the requisite public element. Nor is statutory under-pinning (which is relevant to the matter at issue) conclusive of there being a sufficient public element. ${ }^{63}$ Other criteria may be required to be present.

\section{Power}

It is becoming increasingly clear that important considerations in deciding whether the exercise of power has about it a sufficient public element are the scope or magnitude of that power, whether its exercise has national or international significance and whether its exercise will otherwise remain unchecked in the sense that it creates a monopoly for the body exercising it. These considerations are examined in turn.

"It has been said that 'it is excellent to have a giant's strength, but it is tyrannous to use it like a giant'." 64 In Datafin Lloyd LJ, in holding that there was jurisdiction in respect of the Panel's decisions, pointed to the fact that the Panel wields enormous power. This suggests that it is the aggregation of power which, in part, gives its exercise a public character. However, in The Aga Khan Hoffmann LJ said that the fact that the Jockey Club has power, even over a substantial area of economic activity, is not enough to make its decison-making public. In a mixed economy, he said, power may be private as well as public. Private power may affect the public interest and the livelihoods of many individuals but, in Hoffmann LJ's view, that does not subject it to the rules of public law. The other judgments do not address the issue, and Hoffmann LJ's view appears to be inconsistent with the reasoning in Datafin. While it is true that the fact of power without more (say, an element of control in the regulatory sense) may be insufficient to establish jurisdiction, it should be a factor which the courts take into account. The High Court of Australia has sought to do this in Forbes v. New South Wales Trotting Club $L t d .{ }^{65}$ This was a case involving a challenge by the plaintiff against a decision of

62. In $R$. v. Derbyshire County Council, ex parte Noble [1990] I.R.L.R. 332, 335 Woolf LJ accepted as correct that cases since $R$. v. East Berkshire Health Authority, ex parte Walsh [1984] I.R.L.R. 278 establish that there can be jurisdiction for judicial review even though there is no statutory underpinning of any sort involved.

63. R. v. Derbyshire County Council, ex parte Noble [1990] I.R.L.R. 332, at p. 334 per Woolf LJ. 64. R. v. Panel on Take-overs and Mergers, ex parte Datafin p.l.c. [1987] I All E.R. 564, at p. 582 per Lloyd LJ.

65. 143 C.L.R. 242. 
the respondent Trotting Club warning him off race-courses controlled by it. The plaintiff sought a declaration that the resolution under which the warning off was carried out was ultra vires and void on the ground that there has been no compliance with the rules of natural justice - he had not been given an opportunity to be heard before the resolution was passed. The High Court held that the rules of natural justice applied to the exercise of power. What is of interest about the case is the view of Gibbs and Murphy JJ that the Trotting Club was not in the same position as a private landowner. Murphy J said:66

\begin{abstract}
"When rights are so aggregated that their exercise affects members of the public to a significant degree, they may often be described as public rights and their exercise as that of public power. Such public power must be exercised bona fide, for the purposes for which it is conferred and with due regard to the persons affected by its exercise.... There is a difference between public and private power but, of course, one may shade into the other. When rights are exercised directly by the government or by some agency or some body vested with statutory authority, public power is obviously being exercised, but it may be exercised in ways which are not so obvious."
\end{abstract}

Murphy J held that the Trotting Club was exercising public power and that, in consequence, it could not arbitrarily exclude or remove the plaintiff from racecourses. ${ }^{67}$ Although Forbes concerned the applicability of the rules of natural justice, subsequent Australian cases have treated it as relevant to the question of jurisdiction for judicial review. ${ }^{68}$ The distinction it makes between public and private power has also been approved, ${ }^{69}$ obiter, in Australia - although not yet applied.

If the magnitude and aggregation of power are criteria relevant in assessing the

\title{
66. 143 C.L.R. $242,275$.
}

67. 143 C.L.R. 242, at p. 276 per Murphy J: "When one departs from the purely domestic area of householder and from contracts affecting only individuals, into the sphere where there is an accumulation of rights the exercise of which affects the public to a significant degree, then increasingly, requirements of due process are imposed and arbitrary and unreasonable conduct is not permitted. This approach has been taken to monopolies, contracts in restraint of trade, as well as to statutory authorities. It has also been taken to the conduct of trade unions and clubs in dealing with their members. The question is where the line is to be drawn between public power which requires observance of due process and private power which does not. . . . The stage has been reached where the exercise of power to exclude a person indefinitely from a race-course should be treated as public power subject to due process."

68. E.g., Della-Vedova and Another v. State Energy Commission of Western Australia (1990) 2 W.A.R. 561, at p. 568 per Ipp J (Supreme Court of Western Australia); S. D. Hotop, Principles of Australian Administrative Law 6th ed. (The Law Book Company Ltd., Sydney, 1985), pp. 271-272.

69. Della-Vedova and Another v. State Energy Commission of Western Australia (1990) 2 W.A.R. 561, at p. 568 per Ipp J (Supreme Court of Western Australia); Gerhardy v. Brown 159 C.L.R. 70, at p. 107 per Murphy J; "Sydney" Training Depot Snapper Island Ltd. v. Brown (1987) 14 A.L.D. 464 (Federal Court of Australia). 
public character of the exercise of power, it is possible to envisage a whole new range of powers which now might be subject to control by the supervisory jurisdiction. Private and public companies wield enormous power and their decisions may affect the public, say, environmentally or economically. Is the exercise of power by such bodies now open to challenge on this basis? The development of a principle of administrative law to control the exercise of power, whose public character originates solely from the aggregation of power, is still in its infancy. Limits will have to be set.

The courts have stated ${ }^{70}$ that whether the body exercising the power is in a position of major national importance is to be taken into account in assessing the sufficiency of the public element. In Datafin this criterion was not specifically referred to, and only later cases have interpreted Datafin as according weight to this criterion. ${ }^{71}$ The importance to be accorded to this criterion was illustrated by a New Zealand Court of Appeal decision decided prior to Datafin. In Finnigan v. New Zealand Rugby Football Union Inc. ${ }^{72}$ the plaintiffs, who were not members of the defendant Union, sought a declaration that the defendant's decision to send a New Zealand representative rugby football team to tour South Africa was invalid and unlawful and not made in accordance with the defendant's rules, and an injunction to prevent the defendant implementing the decision. The proceedings were by way of action and not by way of application for judicial review. Nevertheless, the case has considerable relevance in the public law context, given that the defendant was treated as essentially a public body, that standing was accorded by analogy (and possibly by direct application) with public law principles, that one of the grounds of challenge subsequently applied by the High Court in the same case ${ }^{73}$ was akin to a public law ground of challenge, and that the High Court applied a "nature of the power" test. ${ }^{74}$ As the case did not proceed by way of application for judicial review under the New Zealand equivalent to Order 53,75 the Court of Appeal did not address the question of jurisdiction and the sufficiency of any public element. That question was, in effect, subsumed within a consideration of the wider question as to whether the plaintiffs had standing to

70. R. v. Fockey Club, ex parte Massingberd-Mundy (1990) 2 Admin L.R. 609, at p. 628 per Roch J.

71. R. v. The Football Association Ltd., ex parte The Football League Ltd. (unreported, Queen's Bench Division, 31 July 1991, Rose J, LEXIS): ". . . the ratio of [Datafin] is that a body may be subject to judicial review if it regulates an important aspect of national life...".

72. [1985] 2 N.Z.L.R. 159. See P. R. A. Cullum, "The Missed Match", 1990 S.L.T. 25; A. I. M. Tompkins, "Judicial Review and the Public Domain", [1987] N.Z.L.f. 120; M. R. Bowman, "Standing to Challenge the Tour", 5 A.U.L.R. 389; I. Eagles, "Public Law and Private Corporations", [1986] C.L.F. 406; S. L. Watt, "Finnigan v. N.Z.R.F.U.. Judicial Handling of Political Controversy", (1991) 21 V.U.W.L.R. 147; A. C. Hutchinson, "Mice Under a Chair: Democracy, Courts and the Administrative State", (1990) 40 University of Toronto Law Journal 374; D. Oliver, "Is the Ultra Vires Rule the Basis of Judicial Review?", [1987] P.L. 543.

73. Finnigan v. New Zealand Rugby Football Union Inc (No. 2) [1985] 2 N.Z.L.R. 181, at pp. 186-187 per Casey J.

74. Ibid., per Casey J.

75. Judicature Amendment Act 1972 (New Zealand). 
bring proceedings against the defendant. In holding that the plaintiffs did have sufficient standing Cooke J, who delivered the judgment of the Court of Appeal, took into account the fact that the decision of the defendant affected the New Zealand community as a whole and the international relations or standing of New Zealand. He said: ${ }^{76}$

"While technically a private and voluntary sporting association, the Rugby Union is in relation to this decision in a position of major national importance, for the reasons already outlined. In this particular case, therefore, we are not willing to apply to the question of standing the narrowest of criteria that might be drawn from private law fields. In truth the case has some analogy with public law issues."

Even where a body holds a position of major national importance this alone will not be sufficient to confer jurisdiction in the absence of other criteria. ${ }^{77}$ This much is clear from the Court of Appeal's reasoning in The Aga Khan, where it was specifically acknowledged that the Jockey Club was regulating a national activity but that this was not sufficient in the absence of a "governmental" dimension to the regulatory function.

Closely associated with the relevance of the magnitude of the power is the idea that the courts will take into account whether, in exercising the power subject to challenge, a body is securing for itself a monopoly. ${ }^{78}$ What is meant by monopoly? It means that, if a person wishes to take part in a particular activity, then he or she has no alternative but to accept the jurisdiction of the body. Put another way, it means that there is no effective choice but to accept the scrutiny, control and terms and conditions imposed by the relevant body in entering the activity. Consideration was given to the existence of a monopolised market in $R$. v. Lloyd's of London, ex parte Briggs. ${ }^{79}$ Here one of the reasons the Court gave for the view that Lloyd's of London was not exercising a public power in regulating the insurance market was that it was not regulating the whole market, but merely one section of it (Lloyd's powers are derived from a private Act which does not extend to any persons in the insurance business other than those who wish to operate in the section of the market governed by Lloyd's). In The Aga Khan the fact that the Jockey Club had an effective monopoly over the control of racing was not, of itself,

76. [1985] 2 N.Z.L.R. 159, 178-179.

77. E.g., in R. v. Fockey Club, ex parte Massingberd-Mundy (1990) 2 Admin L.R. 609, at p. 630 Roch J recognised that the Jockey Club holds a position of major national importance, but jurisdiction was not conferred.

78. This criterion was not referred to in Datafin itself. Subsequent cases have pointed to its relevance: $R$. v. Fockey Club, ex parte Massingberd-Mundy (1990) 2 Admin L.R. 609, at pp. 628-630 per Roch J; $R$. v. Fockey Club, ex parte R.A.M. Race-courses Ltd. (1991) 3 Admin. L.R. 265, per Stuart-Smith LJ at p. 268 and per Simon Brown J at pp. 293-295.

79. Unreported, Queen's Bench Division, 17 July 1992, Leggatt LJ and Popplewell J, LEXIS. 
sufficient to establish jurisdiction. It seems that the monopoly would have had to have been conferred or enforced by government for it to be relevant.

There are a number of cases not involving judicial review where the courts have intervened to control the exercise of power in reliance on monopoly considerations. Nagle v. Feilden ${ }^{80}$ was a case where the plaintiff had brought an action against the defendants claiming a declaration that the practice of Jockey Club stewards of refusing a trainer's licence to women was void as against public policy and an injunction to order the granting of such a licence. The plaintiff appealed to the Court of Appeal in respect of a decision to strike out the statement of claim and to dismiss the action. The Court of Appeal over-turned the striking out and the dismissal. Lord Denning was of the view that the Jockey Club was an authority exercising a virtual monopoly in an important field of human activity. Of such authorities he said: ${ }^{81}$

"When these authorities exercise a predominant power over the exercise of a trade or profession, the courts may have jurisdiction to see that this power is not abused."

The case has been subsequently followed. ${ }^{82}$ This line of authority has sometimes been confined to the issue of the 'right to work', which is said to be in the same category as cases dealing with the restraint of trade.

It is clear from the case law that, even where there is monopolised power, this of itself is not necessarily conclusive of jurisdiction. What is required is for the monopoly to be conferred, enforced or supported by government for it to have the necessary public character. One can think of the monopolies held by the privatised industries which are enforced by governmental licensing and regulatory agencies. Is the decision-making by companies operating these industries, like the electricity generating and supply companies, sufficiently public so as to establish jurisdiction when they exercise monopolised power of this kind?

\section{Relations with subjects}

A sufficient public element cannot be found merely by equating that phrase with the public interest. ${ }^{83}$ Still less can it be found by taking the public interest in the

80. [1966] 2 Q.B. 633.

81. [1966] 2 Q.B. $633,647$.

82. McInnes v. Onslow Fane and Another [1978] 1 W.L.R. 1520; Cheall v. Association of Professional, Executive, Clerical and Computer Staff [1982] 3 All E.R. 855; Watson v. Prager and Another [1991] 1 W.L.R. 726.

83. R. v. Chief Rabbi, ex parte Wachmann (1991) 3 Admin. L.R. 721, at pp. 727-728 per Simon Brown J; $R$. v. East Berkshire Health Authority, ex parte Walsh [1984] I.R.L.R. 278, per Sir John Donaldson MR at p. 280, per May LJ at p. 283, per Purchas LJ at p. 285; $R$. v. Derbyshire County Council, ex parte Noble [1990] I.R.L.R. 332, at p. 337 per Dillon LJ; R. v. The Football Association Ltd., ex parte The Football League Ltd. (unreported, Queen's Bench Division, 31 July 1991, Rose J, LEXIS). 
sense of "well, the newspapers will make something of it." 84 What is relevant is if the rights of subjects are affected by the exercise of power ${ }^{85}$ The courts will take into account the number of subjects affected by the exercise of the power or decision, ${ }^{86}$ particularly if they are not parties to it. ${ }^{87} \mathrm{~A}$ crucial distinction in this context was made by Roch $\mathrm{J}$ in $R$. v. Fockey Club, ex parte Massingberd-Munday. He saw $^{88}$ the question as whether the exercise of power "affects the applicant's rights qua subject, or [affects] the applicant's rights in a way which is peculiar to him or to a limited class of persons?" This distinction has been subsequently followed. ${ }^{89}$ Thus, where a decision affects only the applicant or everyone in a limited class to which he or she belongs, this will not be sufficient for purposes of the requisite public element. It is only where the decision affects the applicant's rights in the same way that it affects rights of other subjects that that is relevant to the sufficiency of the public element. This reasoning, although not made explicit in The Aga Kha, underlies that decision. The applicant was attempting to challenge a decision which was personal to him and which could not be said to have wider significance for the public.

What kind of "rights affected" are relevant in asking whether the exercise of power affects the applicant's rights qua subject? The applicant's rights may be affected in this way where the exercise of power involves the imposition of discipline or sanction. ${ }^{90}$ But the consequences of that discipline or sanction must not be particular to the applicant, as in the case of The Aga Khan. In some way there must be relevance to the wider public whether, say, by the setting of a new standard of behaviour to which others must now comply or by the creation of a bad precedent applicable in future cases. In McLaren v. The Home Office ${ }^{91}$ Woolf LJ stated, albeit in a case concerning judicial review of decisions made during Crown employment, that what might be required was a challenge to a decision of a

84. R. v. Derbyshire County Council, ex parte Noble [1990] 1.R.L.R. 332, at p. 337 per Dillon LJ. 85. R. v. Panel on Take-overs and Mergers, ex parte Datafin p.l.c. [1987] I All E.R. 564, at pp. 577-578 per Sir John Donaldson MR; Finnigan v. New Zealand Rugby Football Union Inc. [1985] 2 N.Z.L.R. 159, at pp. 178-179 per Cooke J.

86. In $R$. v. The Imam of Bury Park fame Masjid Luton, Abdul Bari and Others, ex parte Sulaiman Ali (unreported, Queen's Bench Division, 30 August 1991, Auld J, LEXIS), one of the reasons that jurisdiction was refused was that the Imam's decision concerned only a comparatively small religious community in Luton.

87. In Datafin, Sir John Donaldson MR pointed to the fact that the Panel's decisions affected many members of the public who were not parties to them.

88. (1990) 2 Admin. L.R. 609, 629.

89.R. v. Derbyshire County Council, ex parte Noble [1990] I.R.L.R. 332, at p. 336 per Woolf LJ; R. v. Royal Life Saving Society, ex parte Howe (unreported, Court of Appeal, 15 May 1990, Lloyd and McCowan LJJ, and Sir John Megaw, LEXIS).

90. E.g., cases where jurisdiction was conferred where there was an exercise of a disciplinary power include: $R$. v. Advertising Standards Authority Lid., ex parte The Insurance Service p.l.c. (1990) 2 Admin L.R. 77; $R$. v. Code of Practice Committee of the British Pharmaceutical Industry, ex parte Professional Counselling Aids Lid. (1991) 3 Admin. L.R. 697; R. v. General Council for the Bar, ex parte Percival (1990) 2 Admin. L.R. 721.

91. [1990] I.R.L.R. 338 . 
disciplinary body which was the applicant's employer or which made a decision which was of general application thereafter in the sense that it was a decision taken as a matter of policy, not in relation to a particular member of staff, but in relation to staff in general. Another kind of way in which the applicant's rights can be affected qua subject is where the power exercised is analogous to a statutory licensing power. This was thought to be relevant in at least two cases, ${ }^{92}$ although in both of them jurisdiction was not conferred. Similarly, where the exercise of power affects the applicant's and others' livelihoods, this may be sufficient.

\section{Other criteria}

The courts in some cases ${ }^{93}$ have cited the lack of a remedy in private law as one reason for conferring jurisdiction. However, the absence of any such remedy should not be relevant to an evaluation of the sufficiency of the public element, and the better view is that the absence of a private law remedy is irrelevant for this purpose. ${ }^{94}$ Its relevance lies in being a consideration to be taken into account in deciding whether to exercise the courts' discretion to grant a remedy once jurisdiction has been conferred. ${ }^{95}$

Where the rules of natural justice are held to apply to the way in which a power is exercised, this will not establish a sufficient public element for purposes of jurisdiction. ${ }^{96}$

At least on one occasion ${ }^{97}$ the courts have said that business, executive or management decisions do not have the requisite public element for purposes of

92.R. v. Jockey Club, ex parte R. A. M. Race-courses Ltd. (1991) 3 Admin L.R. 265; R. v. Chief Rabbi, ex parte Wachmann (1991) 3 Admin. L.R. 721.

93. In R. v. Panel on Take-overs and Mergers, ex parte Datafin p.l.c. [1987] 1 All E.R. 564, at p. 577 Sir John Donaldson MR found that arguments to the effect that the Panel could be adequately controlled by private law were "wholly unconvincing"; $R$. v. fockey Club, ex parte Massingberd-Mundy (1990) 2 Admin L.R. 609, at p. 628 per Roch J. In Finnigan v. New Zealand Rugby Football Union Inc. [1985] 2 N.Z.L.R. 159, at pp. 178-179 Cooke J cited the absence of any other way to control the Union as one reason for conferring standing in that case. In The Aga Khan one of the reasons why the Court of Appeal held jurisdiction was not established was because there existed an alternative remedy by way of action in contract. The Court of Appeal left open the question whether jurisdiction might be established where the alternative remedy of action in contract was unavailable.

94. $R$. v. Lord Chancellor's Department, ex parte Nangle [1991] I.R.L.R. 343, 348; $R$. v. Royal Life Saving Society, ex parte Howe (unreported, Court of Appeal, 15 May 1990, Lloyd and McCowan LJJ, and Sir John Megaw, LEXIS).

95. R. v. Secretary of State for the Home Department, ex parte Benwell [1985] 1 Q.B. 554, 571.

96. R. v. East Berkshire Health Authority, ex parte Walsh [1984] I.R.L.R. 278, at pp. 287-288 per Purchas LJ; R. v. Derbyshire County Council, ex parte Noble [1990] I.R.L.R. 332, at pp. 334-335 per Woolf LJ; R. v. The Football Association Ltd., ex parte The Football League Ltd. (unreported, Queen's Bench Division, 31 July 1991, Rose J, LEXIS).

97. R. v. National Coal Board, ex parte National Union of Mineworkers [1986] I.C.R. 791, at p. 795 per MacPherson J. In R. v. Lloyd's of London, ex parte Briggs (unreported, Queen's Bench Division, 17 July 1992, Leggatt LJ and Popplewell J, LEXIS) it appears that one of the reasons why jurisdiction to review decisions of Lloyd's of London was found not to be established was because it would greatly inhibit the proper discharge of its functions if it had constantly to be looking over its shoulder because of the supposed duty to safeguard the interests of one section of the market (of which the applicants were part). 
jurisdiction. Such statements may now be questionable in the light of Datafin. The character of a decision as commercial or as being a business judgment should not be relevant to the question of jurisdiction, but only to the grounds upon which a challenge can be made. Where one is asserting that a commercial decision should be unreviewable, what is essentially being claimed is that the substance (or merits) of the decision should not be evaluated by the courts. This is orthodox administrative law theory. It breaks no new ground. Why should it not be that the process or procedure by which that decision is reached be subject to judicial scrutiny? What is wrong with requiring a body, in making a business judgment, to comply with its own code in so doing? That is what was essentially required in the cases reviewing the decisions of the Panel, and the same reasoning should apply elsewhere.

\section{PROHIBITION OF JURISDICTION}

In certain circumstances, the nature of the relationship between the parties may preclude success in an application for judicial review. In such cases the relationship can be said to operate as a 'prohibition' against judicial review. In many cases the courts have correctly identified the reason for the prohibition as being the failure to establish a sufficient public element required to establish jurisdiction. However, in cases concerning contracts of membership, as in The Aga Khan, the courts have unfortunately sometimes treated the prohibition as an inflexible rule of policy and one not relating to the question of 'publicness'. The prohibition has been of particular relevance in two types of case. The first is where what is at issue is the employment relationship between the applicant and a public body. ${ }^{98}$ The second is where what is at issue is a contract of membership between a body and the applicant. Until now the courts had not thought to regard the prohibition operating in these two types of case as linked by the similarity of the principles applicable. It is only since the development of the Datafin line of authority that this link has been drawn. That link is, of course, the issue whether the relationship (and in particular the contractual relationship) between the applicant and decision-maker negates the 'publicness' of the decision. The position in England and Scotland in this regard is quite different. An analysis of Scottish law ${ }^{99}$ is beyond the scope of this article, and in any event the position in Scotland is now of less relevance in the English context given that the First

98. For recent analyses, see H. Carty, "Aggrieved Public Sector Workers and Judicial Review", [1991] 54 M.L.R. 129; S. Arrowsmith, "Judicial Review and the Contractual Powers of Public Authorities", (1990) 106 L.Q.R. 277; S. Fredman and G. Morris, "Judicial Review and Civil Servants: Contracts of Employment Declared to Exist", [1991] P.L. 485.

99. See C. M. G. Himsworth, "Public Employment and the Supervisory Jurisdiction", 1992 S.L.T. (News) 123; C. M. G. Himsworth, "Public Employment, the Supervisory Jurisdiction and Point West", 1992 S.L.T. 257; G. I. McPherson, "Judicial Review in Employment", (1992) 37 fournal of the Law Society of Scotland 314; W. J. Wolffe, "The Scope of Judicial Review in Scots Law", [1992] P.L. 625. 
Division of the Court of Session has decisively rejected the distinction, made in English law, between public and private as the basis for conferral of jurisdiction to review under Rule of Court 260B (the Scottish equivalent to Order 53). ${ }^{1}$

The exact scope and nature of the prohibition is unclear. There are several tests which have been applied by the courts. What follows is an evaluation of their relative merit together with an analysis and statement of the underlying principles that should apply. The various tests can be divided into those concerned with contract, those concerned with submission to jurisdiction, those concerned with the status of the decision-maker, and those concerned with whether there is an "additional public law element".

\section{Contract}

One possibility is that jurisdiction might be excluded by the mere existence of a contractual relationship between the decision-maker and the applicant. In Datafin there was apparently a finding that the Panel was not in a contractual relationship with the financial market or with those who deal in that market. ${ }^{2}$ However, in a later case the City Code on Take-overs and Mergers was described as a form of consensual agreement between affected parties, ${ }^{3}$ and in The Aga Khan Hoffmann LJ accepted that "a body such as the Take-Over Panel ... which exercises governmental powers is not any less amenable to public law because it has contractual relations with its members." Datafin left unclear whether the existence of a contractual relationship had any relevance to the conferral of the new jurisdiction it had created. Since then, it has been at least implicit in the reasoning of a number of cases that the mere existence of a contractual relationship between the decision-maker and the applicant will preclude the conferral of jurisdiction. ${ }^{5}$

However, other cases have not taken such a narrow view. Sometimes the courts have specifically addressed the issue, and have held that there is jurisdiction even though there is a contractual relationship. This was so in a Scottish case ${ }^{6}$ and there

\section{West v. Secrezary of State for Scotland 1992 S.L.T. 636.}

2. Lewis argues that it was not clear from the evidence whether there was a contract between members of the Panel or between the Bank of England and the bodies represented on the Panel, and that even if there was, it is not clear whether this would bring about a contractual relationship between individual members of the representative bodies and the Panel. Lewis makes the point that the Panel had jurisdiction over individuals who were not members of any of the representative bodies or had no contractual relationship with the Panel so that, in that instance at least, the Panel had no contractual power: C. Lewis, fudicial Remedies in Public Law (1992), p. 32, n. 27.

3. R. v. Spens [1991] 4 All E.R. 421, at p. 429 per Watkins LJ.

4. At p. 4 .

5. R. v. Football Association of Wales, ex parte Flint Town United Football Club (unreported, Queen's Bench Division, 11 July 1990, Farquharson LJ and Nolan J, LEXIS); $R$. v. Lord Chancellor's Department, ex parte Nangle [1991] I.R.L.R. 343, 346-347; E. Jackson, "Civil Servants and Contracts of Employment", (1992) 21 Industrial Law fournal 64, 66.

6. Bank of Scotland v. Investment Management Organisation Ltd. 1989 S.L.T. 432, at p. 437 per Lord Cullen. Jurisdiction was conceded on appeal. 
is other Scottish authority to that effect. ${ }^{7}$ This authority has gained some support in England. ${ }^{8}$ Moreover, in McLaren v. The Home Office ${ }^{9}$ the Court of Appeal recognised that jurisdiction can exist even where there is a contract of some kind. In Roy v. Kensington and Chelsea and Westminster Family Practitioner Committee, ${ }^{10}$ a case concerning the question of procedural exclusivity under Order 53 (a matter not at issue here), Lord Lowry did not discount the possibility of an application for judicial review being able to be brought even though the applicant may have been in a contractual relationship with the decision-maker. In The Aga Khan the three members of the Court of Appeal relied on differing reasons as to why the contract between the applicant and the Jockey Club negated jurisdiction. However, Hoffmann LJ accepted that bodies such as the Panel or Investment Management Regulatory Organisation Limited which exercise governmental powers are not any less amenable to public law because they have contractual relations with their members. Other cases have at least assumed the existence of jurisdiction even where there is a recognised contractual relationship. ${ }^{11}$ So it can now be said with some confidence that there can be jurisdiction where there is a contractual relationship. This view is clearly correct as a matter of principle. Regardless of whether a contractual relationship is the source of the exercise of the power which is subject to challenge, its existence should be irrelevant under the nature of the power test because that test is not concerned with the source of the power but only with its nature.

Another possibility is that jurisdiction might be excluded when the decisionmaker's authority is derived from a contract with the applicant. It is to be noted that a prohibition formulated in this way differs from a prohibition based on the mere existence of a contractual relationship. The former requires that authority derive from the contract, whereas the latter merely requires the existence of that contract. 'Authority' in this context means the power the exercise of which is being challenged. The idea that jurisdiction might be excluded when the decisionmaker's authority derives from a contract with the applicant follows from the leading case of Law v. National Greyhound Racing Club. ${ }^{12}$ The precise scope of Law's case remains unclear because the Court of Appeal appeared to apply three

7. See C. M. G. Himsworth, "Public Employment and the Supervisory Jurisdiction", 1992 S.L.T. (News) 123; C. M. G. Himsworth, "Public Employment, the Supervisory Jurisdiction and Points West", 1992 S.L.T. 257.

8. Shearson Lehman Hutton Inc. v. Maclaine Watson $\mathcal{E}$ Co. Ltd., f. H. Rayner (Mincing Lane) Ltd. [1989] 2 Lloyd's Law Reports 570, 625.

9. [1990] I.R.L.R. 338.

10. [1992] 2 W.L.R. 239, 261. See Fredman and Morris, "A Snake or a Ladder: O'Reilly v. Mackman Reconsidered", (1992) 108 L.Q.R. 353; P. Cane, "Private Rights and Public Procedure", [1992] P.L. 193.

11. R. v. Association of Futures Brokers and Dealers Ltd. and Another, ex parte Mordens Ltd. (1991)3 Admin L.R. 254;R. v. Kidderminster District Valuer, West Midlands Police Authority and the Secretary of State for the Home Department, ex parte Powell and Police Federation of England and Wales (West Midlands Branch) [1991] 31 R.V.R. 197.

12. [1983] 1 W.L.R. 1302. 
different tests prohibitive of jurisdiction. The first asked whether the decisionmaker's authority derived wholly from contract. The second asked whether there was a voluntary submission to the decision-maker's jurisdiction. The third asked whether the status of the decision-maker was that of a private or domestic tribunal. Implicit in the judgments is the view that all three tests will always give the same answer. But that would not appear to be the case. For example, it is possible to envisage a situation where there is a voluntary submission to jurisdiction but the decision-maker's authority is not derived wholly from contract.

The second and third tests are examined below. As for the first, it finds some support in the case law. In a series of cases, in which the relevant contractual relationship was a contract of membership with the decision-making body, it has been held that jurisdiction is excluded when the decision-maker's authority is derived from a contract with the applicant. ${ }^{13}$ For example, in $R$. v. Lloyd's of London, ex parte Briggs ${ }^{14}$ leave given to a number of Lloyd's Names to seek judicial review of decisions of Lloyd's and its officers arising out of losses incurred in the reinsurance market was set aside for the reason that there was no public element about the exercise of power. The Court held that the exercise of power subject to challenge derived from the contract entered into by the Names with Lloyd's. Without more the case would appear to be authority for the view that power derived from a contract with the applicant will be insufficiently public. However, it is clear that, in reaching its decision, the Court was influenced by the fact that the contract contained what was, in effect, an 'ouster' clause and that the inability of the Names to challenge the decisions of Lloyd's which that clause implied was consistent with the purposes for which Lloyd's existed, so that it would be contrary to those purposes to allow such a challenge. This is really a question of Parliament's intention (Lloyd's having been placed on a statutory footing from which its purposes were construed) as to the availability of judicial review and not at all a question of the effect of contract.

Law's case was cited in argument in Datafin but not in any of the judgments. Lloyd LJ in Datafin said that if "the source of power is contractual, as in the case of private arbitration, then clearly the arbitrator is not subject to judicial review... ."15 This would appear to be consistent with the approach taken in

13. Law v. National Greyhound Racing Club [1983] 1 W.L.R. 1302; R. v. Jockey Club, ex parte Massingberd-Mundy (1990) 2 Admin L.R. 609; R. v. Fockey Club, ex parte R.A.M. Race-courses Ltd. (1991) 3 Admin. L.R. 265 per Stuart-Smith LJ and contra per Simon Brown J; R. v. The Football Association Ltd., ex parte The Football League Ltd. (unreported, Queen's Bench Division, 31 July 1991 , Rose J, LEXIS); $R$. v. Football Association of Wales, ex parte Flint Town United Football Club (unreported, Queen's Bench Division, 11 July 1990, Farquharson LJ and Nolan J, LEXIS); $R$. v. Eastern Counties Rugby Union and Another, ex parte Basildon Rugby Club (unreported, Queen's Bench Division, 10 September 1987, MacPherson J, LEXIS). There are other cases which have cited Law's case as authority in this area but whose judgments were given in reliance on other grounds; $R$. v. Royal Life Saving Society, ex parte Howe (unreported, Court of Appeal, 15 May 1990, Lloyd and McCowan LJJ, and Sir John Megaw, LEXIS); McLaren v. The Home Office [1990] I.R.L.R. 338.

14. Unreported, Queen's Bench Division, 17 July 1992, Leggatt LJ and Popplewell J, LEXIS.

15. [1987] 1 All E.R. 564, 583. 
Law's case. However, the immunity of arbitrators from challenge by way of judicial review is a well-recognised exception, ${ }^{16}$ and for this reason Lloyd LJ's statement should not be regarded as a statement of general principle. In The Aga Khan the Court of Appeal held that Datafin concerned the exercise of "governmental" power. Hoffmann LJ was of the view that because the Jockey Club was not exercising governmental power Law's case applied and its application did not conflict with the principle in Datafin. He was of the view that where there is a contract of membership between the applicant and a body which was a surrogate organ of government (or which exercised governmental power) there may well be a conflict between the principle in Datafin and Law's case, and he appeared to accept that in that instance the principle in Datafin would prevail, giving the example of the Panel and Investment Management Regulatory Organisation Limited as bodies which have contractual relations with their members but which are validly subject to judicial review because they exercise governmental power. As "governmental power" is really another way of referring to public power, Hoffmann LJ's view amounted to little more than saying - quite correctly - that, where a body with whom the applicant has a contract of membership exercises public power, that contract will not negate jurisdiction.

The first test in Law's case refers to authority derived wholly from contract. Where authority is derived partly or wholly from some other source, the prohibition will not apply. ${ }^{17}$ Thus, where the ultimate source of power is statutory but the immediate source of power is a contract between the applicant and decision-maker, in circumstances where the statute has compulsorily imposed both the contract and its terms, it may be that the prohibition will not apply. ${ }^{18}$ Likewise, where the authority is derived partly from a contract of employment and partly from a statute under-pinning that contract, the prohibition may not apply. ${ }^{19}$ Apart from these exceptions, there also exist the cases (discussed above, in dealing with prohibition by mere existence of a contractual relationship) where jurisdiction was conferred despite the existence of a contractual relationship which was also the source of authority.

Without even having to point to these exceptions it is believed that, as a matter of general principle, the first test in Law's case is not, and should not, be applicable to "nature of the power" cases. Law's case was decided at a time when the test of jurisdiction was the source of power, and its reasoning relies on identifiying that source. It is simply not relevant when what is at issue is the nature of the power.

16. Council of Civil Service Unions v. Minister for the Civil Service [1984] 3 All E.R. 935, at pp. 949-950 per Lord Diplock.

17. R. v. Jockey Club, ex parte Massingberd-Mundy (1990) 2 Admin.L.R. 609, at pp. 632-633 per Roch J. 18. This is the view, obiter, of Lloyd LJ in $R$. v. The Independent Broadcasting Authority, ex parte the Rank Organisation p.l.c. (unreported, Court of Appeal, 26 March 1986, May and Lloyd LJJ, and Sir John Megaw, LEXIS).

19. R. v. East Berkshire Health Authority, ex parte Walsh [1984] I.R.L.R. 278; Webster v. Auckland Harbour Board [1983] N.Z.L.R. 646, at p. 650 per Cooke J. 
Another possibility is that jurisdiction might be excluded even when the contract conferring authority on the decision-maker is between the applicant and a third party or between the decision-maker and a third party. Turning first to contracts between the applicant and a third party, the leading case is the Court of Appeal decision of $R$. v. The Independent Broadcasting Authority, ex parte the Rank Organisation p.l.c. ${ }^{20}$ Here the Independent Broadcasting Authority, had power under article 75A of the articles of association of Granada Group p.l.c., in which it was not a shareholder, to refuse to allow any shareholder with more than five per cent of the voting rights to exercise those rights. The Court of Appeal held that the power of refusal arose solely under the articles of association and not under the Broadcasting Act 1981. It was held that there was no jurisdiction. The articles of association constituted a contract between Granada Group p.l.c. and its shareholders (including Rank), but not between those shareholders and the Authority. Thus the Authority derived the power which was subject to challenge from a contract to which it was not a party. That contract allowed it to enforce its power against the applicant, Rank, with whom it was not in a contractual relationship.

The case would appear, prima facie, to be authority for the proposition that the prohibition will apply even where the decision-maker's authority derives from a contract to which it is not a party, although the applicant is party to it. However, the judgments do not rely on such wide reasoning. Rather, at issue was the extent to which the power exercised by the Authority was 'under-pinned' by the provisions of the Broadcasting Act 1981. It is clear from the judgments that, had there been sufficient under-pinning, there would have been jurisdiction. The case is really one where there simply was not a sufficient public element for purposes of jurisdiction. It is not authority for the scope of any prohibition relating to powers derived from contract and, in any event, it pre-dates Datafin and for that reason may no longer be good law.

Moreover, a case in private law with some affinity with the issue of jurisdiction in public law goes against the view in Rank. In Shearson Lehman Hutton Inc. v. Maclaine Watson $\mathcal{G}$ CoLtd., F. H. Rayner (Mincing Lane) $L t d .{ }^{21}$ the plaintiff sued the defendant in respect of contracts for the sale and purchase of tin after the London Metal Exchange, of which only the defendant was a member, purported by a ruling to alter the terms of settlement of the contracts. The plaintiff challenged the Exchange's power to make the rule. Webster J drew on an analogy with public law in applying what may be traditionally regarded as administrative law restraints relevant to the control of the exercise of power by the Exchange. He referred to, and rejected, prohibitions based on the contractual nature of the relationship. Of particular relevance for present purposes is Webster J's view that the Exchange was required to comply with these various public law standards

20. Unreported, Court of Appeal, 26 March 1986, Mary and Lloyd LJJ and Sir John Megaw, LEXIS. 21. [1989] 2 Lloyd's Law Reports 570. 
notwithstanding that the Exchange derived its power, at least so far as it affected the plaintiff, from a contract between the plaintiff and the defendant. The fact that the defendant had a contract of membership with the decision-maker (the Exchange) does not distinguish the case from Rank because the authority conferred on the Exchange to decide matters in respect of the plaintiff was not conferred by that contract.

Turning to cases where the contract conferring authority on the decision-maker to decide matters in respect of the applicant is between the decision-maker and a third party, these also suggest that Rank was not correctly decided. They are relevant to the issue decided in $R a n k$ because they, like Rank, concern the situation where the contract conferring authority on the decision-maker to decide matters in respect of the applicant is not between the decision-maker and the applicant. Although one recent case ${ }^{22}$ suggests that, where there is a contract between the decision-maker and a third party conferring authority on the decision-maker to decide matters in respect of the applicant, the fact of that contract will negate the necessary public element required to establish jurisdiction, of more authority and to contrary effect is the Court of Appeal decision of $R$. v. Life Assurance and Unit Trust Regulatory Organisation Ltd., ex parte Ross. ${ }^{23}$ Here there was a contract of membership between the decision-maker and a third party (conferring authority on the decision-maker to decide matters in respect of the applicant, who was not party to it), and a contract between the third party and the applicant, but no contract between the applicant and the decision-maker. It was conceded, apparently correctly in the view of the Court, that jurisdiction was established. In The Aga Khan the contract at issue was between the Jockey Club (the decisionmaker) and the applicant, and jurisdiction was held not to be established. However, the Court of Appeal specifically left open the question whether jurisdiction could be established when the decision-maker's authority to decide matters in respect of the applicant arose from contract (the contracts of membership with other members), but not one to which the applicant was party. Although The Aga Khan leaves the question open, Shearson and ex parte Ross are to the contrary effect of Rank. Underlying them and recent Scottish authority ${ }^{24}$ to similar effect is the idea that where there is a 'tripartite relationship' between the decision-maker, the applicant and a third party in circumstances where the decision-maker's authority to decide matters in respect of the applicant derives from a contract between the decision-maker and a third party or between the applicant and a third party, jurisdiction to challenge the decision-maker's decision should not be negated merely by reason of the existence of any such contract.

22. R. v. Fernhill Manor School, ex parte Brown (unreported, Queen's Bench Division, 22 May 1992, Brooke J, LEXIS).

23. Unreported, Court of Appeal, 11 June 1992, Glidewell, Stocker and McCowan LJJ, LEXIS. See

A. Lidbetter "Financial Services: The Right to Make Representations", [1992] P.L. 533.

24. West v. Secretary of State for Scotland 1992 S.L.T. 636. 
Rather, at least in English law, jurisdiction can be established if the applicant is able to point to some other factor importing a public element to the decision being challenged.

Another possibility is that jurisdiction might be excluded when the applicant seeks to sue on or enforce the provisions of a contract with the decision-maker. One way of interpreting the prohibition is to have regard to its function or purpose. If the purpose for the rule can be identified then the scope of the rule can be more readily defined. What is the purpose of the prohibition? It seems that the purpose of the prohibition is to prevent an applicant from suing on or enforcing a contractual right or obligation by using public law remedies. Therefore, the prohibition should not apply where the applicant is not seeking to sue on or enforce a contract, even though there may be a contractual relationship and the decision-maker's authority may derive from contract. In fact, $L a w$ 's case supports this approach. The plaintiff sought to proceed by way of ordinary action in contract for a declaration of breach of an implied term, and it was the defendant which sought to force the plaintiff to proceed by way of judicial review. In holding that the plaintiff was not so constrained, the Court of Appeal recognised that the plaintiff's claim was 'based primarily and explicitly on alleged breach of contract." 25

Later cases have specifically applied this approach by asking what it is that the plaintiff is seeking to achieve by bringing the application for judicial review. Purchas LJ applied it in $R$. v. East Berkshire Health Authority, ex parte Walsh. ${ }^{26} \mathrm{He}$ said: 27

\begin{abstract}
"In my judgment the enquiry ought to be directed towards the rights alleged to be infringed and the remedies enjoyed rather that the status enjoyed, qua contract or appointment, by the applicant.... If the remedy sought is a purely private contractual remedy, then it is difficult to see how such a remedy could attract the supervisory powers of the court which were originally limited to the issue of prerogative writs."
\end{abstract}

This statement was approved and applied by Woolf LJ in $R$. v. Derbyshire County Council, ex parte Noble, ${ }^{28}$ and $W$ alsh has since been interpreted as a case where the reason why the applicant could not proceed under Order 53 was because he was seeking to enforce contractual rights. ${ }^{29}$ In The Aga Khan one of the reasons Sir Thomas Bingham MR relied on in holding that jurisdiction was not established was that the applicant was attempting to enforce contractual rights in

25. [1983] 1 W.L.R. 1302, at p. 1312 per Slade LJ.

26. [1984] I.R.L.R. 278.

27. [1984] I.R.L.R. 278, 285.

28. [1990] I.R.L.R. 332, 334 .

29. Doyle v. Northumbria Probation Committee [1991] 4 All E.R. 294, at p. 300 per Henry J. 
judicial review which could be enforced in private law. Other examples where, implicitly, this approach has been applied include McLaren $\mathrm{v}$. The Home Office, ${ }^{30}$ where Woolf $\mathrm{LJ}$ in the Court of Appeal asked what it was that the plaintiff was seeking to achieve. He held that essentially the plaintiff was seeking clarification as to the terms of his employment and a sum alleged due and that these are private law claims, so that the claim should proceed by action. No other public issue arose. Similarly, in $R$. v. Secretary for State for the Home Department, ex parte Benwell ${ }^{31}$ the reason why the applicant was entitled to seek judicial review was because he was not trying to enforce the terms of a contract as, even if there was a contract of employment, the disciplinary procedures which he was trying to have enforced against his employer were not incorporated into it as terms of that contract.

Therefore, where the applicant seeks to enforce rights or obligations which have no nexus with any contract between the applicant and the decision-maker, the applicant will be entitled to pursue them by an application for judicial review. The courts should continue to apply this test. It is both workable and attractive because it takes a functional view of what it is that the applicant is attempting to achieve. It is subject to a qualification, discussed below, that where there is an "additional public law element" the fact that the applicant is seeking to enforce or sue on a contract will not bring the prohibition into play.

\section{Submission to jurisdiction}

Jurisdiction might be excluded when the applicant voluntarily or consensually submits to the jurisdiction of the decision-maker. This is the second test prohibitive of jurisdiction in Law's case. The test has been variously referred to as a voluntary or consensual submission to jurisdiction and as a voluntary entry into a consensual relationship. In Datafin, the Master of the Rolls referred to the exclusion from the supervisory jurisdiction of bodies whose sole source of power is a consensual submission to that body's jurisdiction, and for this reason Farquharson LJ in The Aga Khan was of the view that Datafin and Law's case are consistent. The test has gained support in some later cases, ${ }^{32}$ but in The Aga Khan of the three members of the Court of Appeal only Farquharson LJ thought that this test was what was at issue in Law's case - the other members preferring to treat Law's case as more akin to a rule of policy against review where there is a contract. It is clear, however, that the test of voluntary or consensual submission to jurisdiction is not dependent in its application on the existence of a contractual relationship or on there being authority derived from contract. ${ }^{33}$

30. [1990] I.R.L.R. 338.

31. [1985] 1 Q.B. 554.

32. $R$. v. fockey Club, ex parte Massingberd-Mundy (1990) 2 Admin L.R. 609, at p. 629 per Roch J.; R. v. Jockey Club, ex parte R.A.M. Race-courses Ltd. (1991) 3 Admin. L.R. 265, at pp. 293-294 per Simon Brown J.

33. Counsel's argument to this effect was accepted by the court in $R$. v. Lord Chancellor's Department, ex parte Nangle [1991] I.R.L.R. 343, 347-348. 
The courts have restricted the scope of the test by holding that jurisdiction will not be prohibited unless there is a true submission, a wholly consensual submission or no effective choice. However, in The Aga Khan Farquharson LJ accepted that, if the applicant wished to race horses in Britain he had no choice but to accept the Jockey Club's jurisdiction, but was of the view that that does not destroy the element of consensuality as the applicant is not obliged to race horses in Britain. This more liberal approach as to just what will be consensual should be resisted. It should be the case that there is no true consent or submission if a contract and its terms are imposed compulsorily. ${ }^{34}$ Likewise, persons whose activity is controlled by the rules of a body in circumstances where they have no vote or voice in the amendment of those rules or in their promulgation, and whose only alternative to their accepting those rules is to be excluded altogether from the activity, should be regarded as having no effective choice. ${ }^{35}$ Similarly, an orthodox Rabbi, in pursuing a vocation, has no choice but to accept the Chief Rabbi's disciplinary decisions and the same can be said of members of the Bar and of universities. ${ }^{36}$

On a number of occasions the courts have conferred jurisdiction even though there was clear recognition of there being a consensual submission to jurisdiction. ${ }^{37}$ Some cases have also sought to restrict the test of voluntary or consensual submission to jurisdiction to arbitrators or private or domestic tribunals. ${ }^{38} \mathrm{It}$ is clear, therefore, that despite endorsement by Farquharson $\mathrm{LJ}$ in The Aga Khan, this test is of doubtful use. It has been variously restricted in scope, confined to certain classes of case, exceptions to it have been created or it simply has not been applied.

\section{Status of decision-maker}

Jurisdiction might be excluded when the decision-maker is a voluntary or domestic tribunal. This follows from the third test in Law's case, which asked whether the status of the decison-maker was that of a private or domestic tribunal. This prohibition was promulgated by Lord Parker $\mathrm{CJ}$ in $R$. v. Criminal Injuries

34. R. v. The Independent Broadcasting Authority, ex parte the Rank Organisation p.l.c. (unreported, Court of Appeal, 26 March 1986, May and Lloyd LJJ and Sir John Megaw, LEXIS), per Lloyd LJ (obiter).

35.R. v. Jockey Club, ex parte Massingberd-Mundy (1990) 2 Admin L.R. 609, at pp. 630-631 per Roch J. 36. R. v. Chief Rabbi, ex parte Wachmann (1991) 3 Admin L.R. 721, 727.

37. In Datafin jurisdiction was conferred even though the Master of the Rolls acknowledged that some of those persons affected may in a technical sense be said to have assented to this situation. In $R$. v. Spens [1991] 4 All E.R. 421 Watkins LJ, in delivering the judgment of the Court of Appeal, referred to the City Code on Take-overs and Mergers as a form of consensual agreement between affected parties. In $R$. v. Code of Practice Committee of the British Pharmaceutical Industry, ex parte Professional Counselling Aids Ltd. (1991) 3 Admin. L.R. 697 jurisdiction was conferred even though Popplewell J at p. 718 said that, although the applicant was not in a contractual relationship with the respondents, he voluntarily submitted to their jurisdiction. See also $R$. v. Association of Futures Brokers and Dealers Ltd., and Another, ex parte Mordens Lid. (1991) 3 Admin. L.R. 254, 260.

38. R. v. Chief Rabbi, ex parte Wachmann (1991) 3 Admin. L. R. 721, 727; R. v. Jockey Club, ex parte R.A.M. Race-courses Ltd. (1991) 3 Admin. L.R. 265, at pp. 293-294 per Simon Brown J. 
Compensation Board, ex parte Lain, where he said: ${ }^{39}$

"Private or domestic tribunals have always been outside the scope of certiorari since their authority is derived solely from contract, that is, from the agreement of the parties concerned."

A prohibition in those terms was referred to by Lloyd LJ in Datafin and it has been occasionally applied by the courts. ${ }^{40}$ However, there is some conflicting Australian authority in this regard. Although there is some Australian authority taking the orthodox view that the decisions of domestic, private or voluntary tribunals are unreviewable, ${ }^{41}$ there are dicta of the Australian courts suggesting that, where a domestic or private body is exercising public power, the exercise of that power will be reviewable..$^{42}$ In fact, this accords with the approach to be taken under the nature of the power test. It is not the status of the body, but the public character of the exercise of the power, which determines jurisdiction. Simon Brown J supported this view in $R$. v. Fockey Club, ex parte R.A.M. Race-courses $L t d .{ }^{43}$ and in The Aga Khan Hoffmann LJ saw "no reason why a private club should not also exercise public powers." 44

The main problem with a prohibition focusing on the status of a body as private, domestic or voluntary is that that status has never been adequately defined or prescribed by the courts and nor has the test been consistently applied. It has been suggested that domestic tribunals are tribunals "whose jurisdiction is confined to the internal affairs of some profession or association. . ." 45 But this definition is quite inadequate. It could easily be said that the Ethical Committee of St. Mary's Hospital, ${ }^{46}$ the Code of Practice Committee of the British Pharmaceutical Industry, ${ }^{47}$ the General Council for the Bar, ${ }^{48}$ the London Metal Exchange, ${ }^{49}$ and the New Zealand Rugby Football Union ${ }^{50}$ are all bodies whose jurisdictions are confined to the internal affairs of their respective professions or associations, yet in

39. [1967] 2 Q.B. 864, 882.

40. E.g., R. v. The Football Association Ltd., ex parte The Foorball League Ltd. (unreported, Queen's Bench Division, 31 July 1991, Rose J, LEXIS).

41. E.g., Dixon v. Australian Society of Accountants (1989) 95 F.L.R. 231, at p. 238 per Miles CJ.

42. Della-Vedova and Another v. State Energy Commission of Western Australia (1990) 2 W.A.R. 561, at p. 568 per Ipp J (Supreme Court of Western Australia); S. D. Hotop, Principles of Australian Administrative Law 6th ed. (1985), pp. 271-272.

43. (1991) 3 Admin. L.R. 265, 293-294.

44. At p. 1 .

45. H. W. R. Wade, Administrative Law 6th ed (1988), p. 647.

46. R. v. Ethical Committee of St. Mary's Hospital (Manchester), ex parte Harriou [1988] I F.L.R. 512. 47. R. v. Code of Practice Committee of the British Pharmaceutical Industry, ex parte Professional Counselling Aids Ltd. (1991) 3 Admin. L.R. 697.

48. R. v. General Council for the Bar, ex parte Percival (1990) 2 Admin. L.R. 721.

49. Shearson Lehman Hutton Inc. v. Maclaine Watson $\mathcal{G}$ Co. Lid., 7 . H. Rayner (Mincing Lane) Ltd. [1989] 2 Lloyd's Law Reports 570.

50. Finnigan v. New Zealand Rugby Football Union Inc. [1985] 2 N.Z.L.R. 159. 
each case jurisdiction was conferred. In any event, it is not the status of the decision-maker which is relevant, but the nature of the decision itself. Just as public bodies can make decisions which are 'private' and therefore unreviewable, so too may private bodies make 'public' decisions which are reviewable. To ask whether a body is domestic merely begs the question. A body is defined by the nature of its powers. It may be public for some purposes and private for others. Given that the test is problematic with respect to application and has not been consistently applied it would be preferable to discard it.

\section{Additional public law element}

Jurisdiction might be excluded unless there is an 'additional public law element'. Thus, where there is a contractual relationship or the decision-maker's authority is derived from contract, an 'additional public law element' will establish a sufficient public element for purposes of jurisdiction..$^{51}$

What is meant by an 'additional public law element'? Assuming that the applicant has a contract with the decision-maker, there will be an additional public law element where the subject-matter of the application for judicial review arises out of that contract, and:

1. the applicant's dispute over some aspect of the contractual relationship has been decided upon by a body external to the decison-maker;

2. the applicant is adversely affected by a decision of general application made by the decision-maker. This will include decisions as to general policy applicable to all, and not merely the applicant;

3. the decision-maker's decision, in relation to the applicant, sets an adverse precedent for future cases;

4. the decision-maker's decision concerns the interpretation of its own legal powers;

5. generally, the decision-maker's decision has repercussions not limited to the applicant.

\section{Conclusions}

Having reviewed and evaluated the various possible tests for the prohibition, it is possible to formulate some rules which should be of general application. Where there is a contractual relationship or the decision-maker's authority is derived from contract, and the applicant:

1. is seeking to enforce or sue on the contract, there will not be jurisdiction unless there is an additional public law element;

2. is not seeking to enforce or sue on the contract, there will be jurisdiction if 
there is a sufficient public element. A sufficient public element is established in the usual way by applying the criteria discussed in this article. It may also be established by pointing to an additional public law element.

\section{THE FUTURE}

What is interesting about the development of the control of the exercise of public power by way of judicial review is that it allows the courts to make a qualitative assessment of the nature of the power being exercised and to evaluate in functional terms the wider constitutional or governmental role of bodies whose decisions are being challenged. That is why it is a pity that the Court of Appeal in The Aga Khan should have chosen to endorse the 'rule' in Law's case and to have concerned itself so with matters of contract. Contract is not the issue. The real issue facing the courts is a question of judicial policy about the extent to which they are prepared to place fetters on the workings of a system of devolved State decision-making. In these days of privatisation when the State is being "rolled back", and being replaced with surrogate organs of government, it is interesting to speculate about the point at which the courts will say that power delegated in this way ceases to be public for purposes of judicial review. If the views of the Court of Appeal in The Aga Khan are anything to go by, a close connection with government and incorporation within an enacted framework of public regulation might be required. 